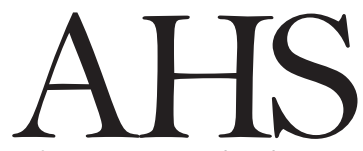

Advances in Horticultural Science

\section{Prospects for improvement of Plectranthus edulis (Vatke) Agnew: A high potential food security crop}

\author{
T. Feyissa \\ Institute of Biotechnology, Addis Ababa University, Addis Ababa, Ethiopia.
}

Key words: Genetic diversity, micropropagation, neglected crops, nutritional composition, tuber.

OPEN ACCESS

(*) Corresponding author: $^{\text {tileye.feyissa@aau.edu.et }}$

Citation:

FEYISSA T., 2021 - Prospects for improvement of Plectranthus edulis (Vatke) Agnew: A high potential food security crop. - Adv. Hort. Sci., 35(3): 319-327.

Copyright:

(C) 2021 Feyissa T. This is an open access, peer reviewed article published by Firenze University Press (http://www.fupress.net/index.php/ahs/) and distributed under the terms of the Creative Commons Attribution License, which permits unrestricted use, distribution, and reproduction in any medium, provided the original author and source are credited.

Data Availability Statement:

All relevant data are within the paper and its Supporting Information files.

Author Contributions:

All authors contributed equally to the work.

Competing Interests:

The authors declare no competing interests.

Received for publication 17 January 2021 Accepted for publication 16 July 2021
Abstract: Plectranthus edulis (Vatke) Agnew is a tuber crop originated and cultivated in Ethiopia for food and medicinal uses. It has higher quality nutrient composition than other tuber crops. The cultivation of $P$. edulis is under threat because of introduction of exotic species, land use change, habitat destruction, population pressure, selection of only few local varieties by farmers and climate change. Although $P$. edulis is a high potential food security crop, there is no any improved variety as there has been very little research on the crop. This lack of research attention including absence of improved varieties and lack of conservation strategy may lead to significant genetic erosion of this crop. Previous studies of $\boldsymbol{P}$. edulis include documentation of indigenous knowledge, analysis of nutritional composition and the use of its starch in drug formulation, traditional cultivation practices, micropropagation, in vitro regeneration, and morphological and molecular genetic diversity. However, more extensive research in all aspects is required for its improvement, use and conservation. Therefore, it is imperative to review the research results of this crop for the research community. This article reviewed research findings of this crop and presents it in a comprehensive way so that the readers will get ample information and can refer original research findings for the details.

\section{Introduction}

Plectranthus edulis (Vatke) Agnew (synonym. Coleus edulis) is an ancient indigenous tuber crop that occurs both as cultivated and wild species in Ethiopia. Although it is known by different local names depending on the place where it is cultivated, Oromo dinich is the most popular local name. The cultivation of $P$. edulis is restricted to Ethiopia. It is mainly cultivated in the south and south western parts of the country at altitudes ranging between 1880 and $2200 \mathrm{~m}$ a.s.l. as food, and sometimes medicine (Demissie, 1988; Taye et al., 2007; Megersa, 2010). P. edulis is a dicotyledonous plant that grows up to a height of $1.5 \mathrm{~m}$ (Taye, 2008).

$P$. edulis is a high energy food crop and the tubers contain substantial amounts of micro- and macro-nutrients. When compared to Irish potato 
(Solanum tuberosum), P. edulis has higher food energy and contains twice the amount of fat and calcium (EHNRI, 1997). It contains a similar amount of protein to that of Irish potato and almost twice that of sweet potato (Ipomoea batatas) after cooking (EHNRI, 1997).

The cultivation of $P$. edulis is under threat because of a decline in diversified local food production systems as a result of introduction of exotic species, land use change, habitat destruction, population pressure, selection of only a few local varieties by farmers, farming system intensification and climate change (Smolders, 2006; FAO, 2010). The decline in cultivation of the crop may result in erosion of the genetic base preventing the use of distinctive useful traits that are used for crop adaptation and improvement (Padulosi et al., 2002; IBC, 2005).

There is enormous untapped potential in Ethiopia to exploit the rich and diverse plant genetic resources of underutilized root and tuber crops including $P$. edulis. In spite of this potential, very little research has been done to improve the productivity of $P$. edulis (IBC, 2007). Currently, however, $P$. edulis is realized as a high potential food security crop that is attracting research attention.

The poor storability of tubers is found to be the major production constraint of $P$. edulis. It is propagated by vegetative methods so that it is susceptible to diseases that are transmitted from one generation to the next through infected planting material (Taye, 2008). This problem can be solved by integration of new technologies including biotechnological approaches. Documentation of information on indigenous knowledge, uses, and distribution of this crop is essential for its conservation, further utilization, and improvement (Mathenge, 1995). It is also important to initiate research on seed production of $P$. edulis. So far, there is no any improved variety of $P$. edulis. The objective of this article is to review some aspects of this crop, with particular regard to biotechnological approaches and present it in a comprehensive way so that the readers will get summarized information to design research or policy on conservation and improvement of the crop.

\section{Production practices}

Farmers select seed tubers from the previous harvest or they buy from the market. Most farmers plow the land more than three times before planting and mix farmyard manure with the soil (Mekbib and Weibull, 2012). Farmers do not use chemical fertilizers and other commercial inputs for production of $P$. edulis. The seed tubers are planted from March to April as there is brief rain during this time. Farmers commonly slice a single tuber into pieces and plant the pieces because they claim planting tuber pieces increases tuber yield (Taye et al., 2007; Mekbib and Weibull, 2012). Research findings also showed that planting tuber pieces results in higher yields than whole tubers (Taye, 2008).

In southern Ethiopia, almost $50 \%$ of the farmers plant the tubers with their sprouts whereas the others plant after removing the sprouts (Taye, 2008). Most $P$. edulis growing farmers remove the shoot apex with one or two pairs of leaves from the main stem and branches to increase stem number. Research results show that this practice significantly increases the number of stems and enhances faster stolen formation. Most farmers commonly build up the soil around the stem to enhance plant growth and increase tuber yield. The absence of positive correlation between frequency of removing the shoot apex and amount of the soil built up around the stem was reported, although both activities serve the same purpose (Taye, 2008).

Weeding is carried out at least three times at different growing stages of $P$. edulis. Following harvest of $P$. edulis, farmers plant other crops, and the yields of crops that follow $P$. edulis in the rotation are high. The reason for increase in yield could be due to the slowly released nutrients into the soil and improved soil structures as the result of the organic manure applied in previous cropping seasons (Mekbib and Weibull, 2012). Depending on the type of variety, $P$. edulis is harvested from six to eight months after planting. Although the cultivation is mainly performed by male farmers, female farmers also play important roles in selecting tubers for different enduse criteria related to the household food requirements (Mekbib and Weibull, 2012).

Farmers used to maintain several local varieties of $P$. edulis for different purposes. However, the number of local varieties preserved by farmers has been declining. So far, the total number of local varieties all over the country is not known. However, there are at least six local varieties of $P$. edulis that grow in specific areas as study results on three kebeles (the smallest administrative units in Ethiopia), namely Delebo-atewaro, Delebo-wogene and Kokete-marechare of Sodo Zuria district, South Ethiopia have 
shown (Mekbib and Weibull, 2012). Growth habits, taste, tuber skin color, days to maturity, drought tolerance, storage period and marketability are the main characteristics of the plant used by farmers to identify local varieties (Mekbib and Weibull, 2012). Distribution and seed exchange of local varieties by farmers play key roles in conservation and utilization of local varieties (de Boef, 2008). Younger farmers mostly purchase the planting material from markets whereas older farmers (older than fifty years) use their own saved seed tubers from the previous harvest. Older farmers have much richer indigenous knowledge than younger farmers about the cultural value of the crop, indicating a limitation in the documentation of knowledge on the management. These knowledge gaps may lead to cultivation of only few local varieties (Negri, 2003; Mekbib and Weibull, 2012). This calls for more research on documentation of local knowledge and transferring this knowledge to the young farmers.

One of the major challenges of $P$. edulis production is seed tuber storage. The tuber is stored in the field where it is produced until used for the required purpose. This storage method results in significant tuber yield loss due to excessive heat especially during dry seasons. The land where the tubers are stored remains idle until all the tubers are removed. Therefore, as farmers do not want their land to be idle, most of them often obtain seed tubers from other sources during planting season (Mekbib and Weibull, 2012). Farmers cover $P$. edulis fields with mulching materials to protect the tubers from direct sunlight until the next planting season. After the preparation of the land for planting, tubers are transferred to the pits for a day to facilitate the germination and performance of seedlings. Most seed tubers are obtained from farmers who have enough land to produce $P$. edulis as they produce more than a household requirement and save the surplus for sale (Negri, 2003). Although different cultural practices have been designed to overcome the production constraints of $P$. edulis, very little research has been done to tackle the problems. Another important constraint is shortage of land for planting (Mekbib and Weibull, 2012). This can be solved by amending land usage policy.

Some efforts have been made to evaluate performance of $P$. edulis with regard to yield and yield related characters and reports show different performance of the crop at different environments (Taye et al., 2013). Tuber fresh weights of 4556-4933 $\mathrm{g} \mathrm{m}^{-2}$, or 45-49 Mg ha-1 were obtained at experimental sites, which is higher than yields produced by farmers (740-1480 $\mathrm{g} \mathrm{m}^{-2}$ ). This higher experimental yields compared to farmers' yields is because farmers harvest the tubers early Late emergence, slow development of the canopy, full coverage of the ground in a short period of time and decline in soil cover during senescence caused poor radiation interception. Radiation interception of a crop can be enhanced by increasing ground cover by the canopy. This could be achieved by planting large seed tuber pieces (Wiersema and Cabello, 1986; Lommen and Struik, 1994), by planting more tuber pieces per area (Spitters, 1990) or by using traditional practices that enhance the canopy development (Taye et al., 2012).

\section{Nutritional content}

P. edulis contains substantial amounts of nutrients. Moisture content of the tuber dry matter ranges from $14.1 \%$ to $17.5 \%$, whereas the protein content ranges from $0.70 \%$ to $1.76 \%$ (Hellemans et al., 2017). These values are higher than cassava tuber, which contains $0.3 \%$ protein and $0.1 \%$ to $0.3 \%$ starch (Alvani, 2011; Waterschoot et al., 2015). Another study reported $11.2 \%$ moisture, $0.14 \%$ ash, $0.21 \%$ lipid, $0.43 \%$ protein, and $99.22 \%$ starch content on a dry weight basis (Assefa, 2015) (Table 1).

Table 1 - Proximate composition of Plectranthus edulis tubers on dry weight basis in g per $100 \mathrm{~g}$

\begin{tabular}{lcccccccc}
\hline Sample type & $\begin{array}{c}\text { Moisture } \\
\text { content } \\
(\%)\end{array}$ & $\begin{array}{c}\text { Crude } \\
\text { protein }\end{array}$ & $\begin{array}{c}\text { Total } \\
\text { ash }\end{array}$ & $\begin{array}{c}\text { Crude } \\
\text { fiber }\end{array}$ & $\begin{array}{c}\text { Crude } \\
\text { fat }\end{array}$ & Carboydrate & $\begin{array}{c}\text { Energy } \\
\text { (Calories) }\end{array}$ & References \\
\hline Raw & 81.9 & 1.5 & 1.1 & 0.70 & 0.20 & 15.3 & 69 & EHNRI ${ }^{(z)}, 1997$ \\
Boiled & 73.8 & 1.0 & 1.3 & 1.00 & 0.20 & 23.7 & 101 & EHNRI, 1997 \\
Starch & 11.2 & - & 0.14 & - & 0.21 & 99.2 & - & Assefa, 2015 \\
Starch & 15.5 & 1.09 & & 3.0 & 0.24 & - & - & Alvani et al., 2011 \\
\hline
\end{tabular}

(z) Ethiopian Health and Nutrition Research Institute 
Samples collected from different regions of Ethiopia showed variation in fiber content based on their geographic location. Starch extracted from tuber samples collected from Wolaita zone (Chenqoua, Inuka and Lofua areas) showed significantly lower fiber content than tuber samples collected from Arjo white, Chencha and Jarmet. Moreover, the samples collected from Arjo white, Chencha and Jarmet contain higher fiber content than cassava or potato. Whether this variation is due to the environment or genetic variation needs further investigation. P. edulis contains amylase ranging from $14.2 \%$ to 23.9\% (Waterschoot et al., 2015).

Tuber samples collected from Abay Chomen district of Oromia Region, Ethiopia, showed variation in mineral content may be due to genotype or environmental variation. $P$. edulis is found to be rich in potassium followed by magnesium, calcium, zinc, manganese, and copper. Mineral content of $P$. edulis is presented in Table 2. The trace metals (chromium and nickel) and the heavy metals (lead and cadmium) were not detected, indicating $P$. edulis is safe with regard to the toxic heavy metal health concerns (Lema, 2016). The phosphorus content of most $P$. edulis samples is twice as much as in Irish potato. High phosphorus content is linked to resistant starch, paste viscosity and gel strength (Lu et al., 2012). Higher phosphorus content is responsible for the granular structure, and especially for the crystalline region to be less rigid and therefore enabling absorption of more water (Lin et al., 2013). High phosphorus content was also found to impart high viscosity to the starch and increase gel strength. This indicates $P$. edulis starch can be used in food processing that requires high gel strength and can provide resistant starch in functional food preparation (Hellemans et al., 2017). However, further research should be conducted to confirm this finding. P. edulis is found to be richer in most of the mineral elements than Irish potato.

\section{Starch physicochemical properties}

Scanning Electron Microscopy (SEM) of the starch granules showed elliptical and some oval shapes. The starch showed a normal monomodal granule size distribution. X-Ray Diffraction pattern of the starch showed typical B-type with a distinctive peak (Assefa, 2015). On the contrary, other authors reported distinct bimodal distribution pattern of starch granular characteristics, which indicates the presence of small (B-type) and large (A-type) granules (Hellemans et al., 2017). The shape of B-type granules is spherical whereas that of A-type is elliptical when visualized by the cryo-SEM. For starch extracted from $P$. edulis tuber, such bimodal distribution is not common. Starch extracted from Irish potato and cassava shows normal distribution pattern (Waterschoot et al., 2015). Therefore, $P$. edulis can be used in food industry and as an alternative for potato starch, which is less suitable to be used in pasteurized foods.

Typical water absorption (WA) pattern, swelling power and relative humidity of $P$. edulis is reported to be higher than Irish potato starch but its solubility at all studied temperatures is lower than Irish potato (Assefa, 2015). The physicochemical analysis of the starch showed $1.08 \mathrm{~g} / \mathrm{g}$ WA of $P$. edulis (Hellemans et al., 2017). This means that the starch granules absorb on average of 1.08 times their own weight after it is completely hydrated. Only a small difference was observed in WA among $P$. edulis starch samples of different accessions. The high water binding ability of the starch could reduce the stickiness of dough, increase moistness, improve handling and soften the texture of baked products, which makes $P$. edulis starches more suitable for use in baked goods (Taggart, 2004).

Differential Scanning Calorimeter (DSC) thermograms of $P$. edulis starch showed higher onset temperature (To) of $69.2^{\circ} \mathrm{C}$, peak temperature (Tp) of $74.3^{\circ} \mathrm{C}$ and ending temperature (Te) of $83.3^{\circ} \mathrm{C}$ than the starch of Irish potato (Assefa, 2015). Similarly, the pasting properties showed $P$. edulis starch has

Table 2 - Mineral content of Plectranthus edulis in mg per $100 \mathrm{~g}$

\begin{tabular}{|c|c|c|c|c|c|c|c|}
\hline Sample & K & $\mathrm{Ca}$ & $\mathrm{Fe}$ & $\mathrm{Mg}$ & $\mathrm{Zn}$ & $P$ & References \\
\hline Raw & - & 29.0 & 9.30 & - & - & 90.0 & EHNRI, 1997 \\
\hline Boiled & - & 19.0 & 1.10 & - & - & 62.0 & EHNRI, 1997 \\
\hline Starch w & 513 & 397 & 20.8 & 175 & 4.5 & 1803 & Alvani et al., 2011 \\
\hline Starch & 3.54 & 0.62 & - & 0.49 & 0.24 & - & Lu et al., 2012 \\
\hline
\end{tabular}

${ }^{w} \mathrm{ppm} / \mathrm{dm}$ - parts per million/dry matter. 
higher pasting temperature than Irish potato (Hellemans et al., 2017). A rapid increase in viscosity occurred at $\mathrm{Tp}$ range of 70.7 to $74.0^{\circ} \mathrm{C}$ compared to Irish potato starch $\left(52.2^{\circ} \mathrm{C}\right)$.

The disintegrating abilities of starch of $P$. edulis and Irish potato were compared in paracetamol tablet formulations prepared by wet granulation method (Assefa, 2015). The granules were prepared with the starches at different disintegrant concentrations and characterized for particle size distribution and flow properties. The prepared tablets showed excellent flow property as manifested by the weight uniformity. After studying the crushing strength, friability, disintegration time, and dissolution rate of the tablets using standard methods, the results showed that $P$. edulis starch favorably competed with potato starch as a disintegrant in the paracetamol tablet formulations.

In other recent study, carboxymethylated $P$. edulis starch was evaluated as a suspending agent in metronidazole benzoate suspensions by comparing with sodium carboxymethyl cellulose (NaCMC) (Brhane, 2020). The author reported viscosities of the formulations prepared with carboxymethylated $P$. edulis starch were significantly lower than that of $\mathrm{NaCMC}$. The flowability of the suspensions was in the order of carboxymethylated $P$. edulis starch (CMPS) greater than NaCMC. At $1 \%$ concentration, carboxymethylated $P$. edulis starch resulted in significantly higher sedimentation volume than NaCMC. Potassium dihydrogen phosphate $\left(\mathrm{KH}_{2} \mathrm{PO} 4\right)$, which is employed as a flocculating agent, significantly increased the sedimentation volume of the suspensions prepared with carboxymethylated $P$. edulis starch and NaCMC. The redispersibilities of CMPS were found to be better than NaCMC. The author pointed out that all suspensions resulted in a release of greater than $85 \%$ of drug within $1 \mathrm{~h}$. All suspension formulations were found to be stable (Brhane, 2020). The author concluded carboxymethylated $P$. edulis starch can be used as alternative suspending agent.

\section{Prospects of biotechnology for improvement of P. edulis}

In addition to the shortage of seed tubers and the poor storability of the tubers, systemic diseases, viruses, viroids and mycoplasma as well as several pathogenic bacteria are the most devastating root and tuber crops including $P$. edulis, in terms of yield loss
(Bryan, 1983). These problems might be solved by using the benefits of modern plant biotechnology such as plant tissue culture that can supply a large number of disease-free planting materials to growers who continually acquire it.

\section{Micropropagation and in vitro shoot regeneration}

Increased use of rapid multiplication techniques enables production of large amounts of pathogenfree planting material. Most rapid multiplication techniques in root and tuber crops involve the use of aerial portions of the plant so that contact with soil and tuber is broken and most non-systemic pathogens can be eliminated (Bryan, 1983). Meristem culture is the most popular tissue culture technique for production of disease free planting materials. It can be used alone or in combination with thermotherapy to eliminate a number of viruses and bacteria (Kartha and Gamborg, 1975). Meristem culture technique eliminates systemic pathogens found in the mother stock plant.

The first micropropagation protocol of $P$. edulis was developed from meristem culture (Tsegaw and Feyissa, 2014) followed by in vitro shoot regeneration from leaf derived callus (Aschale and Feyissa, 2019). Shoots were initiated from meristem explants using Murashige and Skoog (MS) (Murashige and Skoog, 1962) medium. The MS medium was supplemented with $1.0 \mathrm{mg} / \mathrm{l}$ gibberellin $\left(\mathrm{GA}_{3}\right)$ and $0.1 \mathrm{mg} / \mathrm{l}$ $\alpha$-naphthalene acetic acid (NAA) in combination with different concentrations of benzylaminopurine (BAP) (Tsegaw and Feyissa, 2014). According to the authors, MS medium containing the aforementioned hormones was proved to be the best in terms of shoot initiation from meristem for mother plants collected from two locations, Holeta and Wolaita. The shoots were transferred to multiplication medium and the highest mean shoot number per explant (7.2) was obtained on medium containing $1.0 \mathrm{mg} / \mathrm{l}$ kinetin in combination with $0.1 \mathrm{mg} / \mathrm{l}$ NAA for shoots derived from mother plants collected from Holeta while, 6.2 shoots per explant was obtained on medium containing $3.0 \mathrm{mg} / \mathrm{l}$ kinetin in combination with $0.05 \mathrm{mg} / \mathrm{l} \mathrm{NAA}$ for shoots derived from mother plants collected from Wolaita. The effect of solid and liquid media on in vitro axillary shoot proliferation was investigated by culturing shoots on MS medium containing different concentrations of BAP in combination with thidiazuron (TDZ) (Yimam, 2013). The highest mean shoot number per explant, 5.85 and 6.07 , were obtained on solid and liquid media, 
respectively, containing $1.5 \mathrm{mg} / \mathrm{I} \mathrm{BAP}$ in combination with $0.5 \mathrm{mg} / \mathrm{l} \mathrm{TDZ}$.

Developing in vitro regeneration protocol through callus phase or somatic embryogenesis is a prerequisite to genetically improve a crop through biotechnological approaches including genetic engineering, genome editing and creating somaclonal variants. Recently, in vitro regeneration protocol of $P$. edulis have been developed by using leaf explants (Aschale and Feyissa, 2019). The highest percentage of callus induction (100\%) was obtained on MS medium supplemented with $1.5 \mathrm{mg} / \mathrm{I}$ NAA in combination with $1.0 \mathrm{mg} / \mathrm{l} \mathrm{BAP}$ and $2.0 \mathrm{mg} / \mathrm{l} \mathrm{NAA}$ in combination with $0.5 \mathrm{mg} / \mathrm{l}$ BAP. The highest shoot regeneration percentage $(46.6 \%)$ from callus was obtained on MS medium containing $0.1 \mathrm{mg} / \mathrm{l}$ BAP in combination with $0.5 \mathrm{mg} / \mathrm{I} \mathrm{TDZ}$. The highest mean shoot number per callus (1.66) was obtained on medium containing 1.5 $\mathrm{mg} / \mathrm{I}$ BAP in combination with $1.0 \mathrm{mg} / \mathrm{l} \mathrm{TDZ}$. The highest mean shoot length $(0.63 \mathrm{~cm})$ was obtained on medium supplemented with $0.5 \mathrm{mg} / \mathrm{l} \mathrm{BAP}$ in combination with $0.1 \mathrm{mg} / \mathrm{l} \mathrm{TDZ}$. The highest mean shoot number per explant (58.68) was obtained on medium supplemented with $0.5 \mathrm{mg} / \mathrm{l}$ BAP in combination with $0.4 \mathrm{mg} / \mathrm{l} \mathrm{GA3}$.

\section{Rooting and acclimatization}

Shoots cultured on half salt strength MS medium rooted better than those cultured on full salt strength (Tsegaw and Feyissa, 2014). Shoots derived from explants collected from Holeta resulted in the highest percentage of rooting (100\%) and 3.12 mean root number per shoot whereas shoots whose explants were collected from Wolaita resulted in $76.7 \%$ rooting and 2.2 mean root number per explant. Microshoots were also directly planted in a greenhouse for rooting and acclimatization by bypassing the in vitro rooting stage and the overall best result in rooting was obtained in ex vitro rooting condition. It was promising in cost reduction as it bypasses the in vitro rooting stage. Reducing the cost of in vitro production is a key for increasing the application of the method. Rooting of microshoots in vitro is expensive and can even double the price of the plantlets (Zimmerman, 1988; De Klerk, 2002). In another study, shoots were cultured on half strength MS medium containing different concentrations of indole acetic acid (IAA) and indole butryic acid (IBA) for rooting (Yimam, 2013). The highest mean root number per shoot (10.55) was obtained on solid medium and 13.11 mean root number per shoot was obtained in liquid medium containing $0.1 \mathrm{mg} / \mathrm{I}$ IAA. The highest mean root number per shoot of 10.15 on MS medium supplemented with $2.0 \mathrm{mg} / \mathrm{I} \mathrm{IBA}$ was also reported (Aschale and Feyissa, 2019).

All in vitro regenerated plants of Holeta origin and $96 \%$ of Wolaita origin survived after one month of acclimatization in a greenhouse. Similar study reported $100 \%$ and $82.85 \%$ survival of plantlets derived from solid and liquid media, respectively, after acclimatization in greenhouse (Yimam, 2013). All in vitro rooted and $78 \%$ ex vitro rooted microshoots survived in the greenhouse (Aschale and Feyissa, 2019). The development of these protocols for micropropagation and in vitro regeneration of shoots from callus is the prerequisite for further advanced biotechnology research such as genetic transformation and genome editing of this crop.

\section{Genetic diversity of $P$. edulis}

For improvement of any crop, the existence of adequate genetic diversity is imperative. This could be achieved if and only if there is appropriate conservation strategy. Selection and cultivation of only few local varieties of $P$. edulis and its current replacement by other tuber crops has been causing serious genetic erosion of the local gene pool of this crop.

\section{Genetic diversity analyses using morphological traits}

There are several studies on morphological genetic diversity of $P$. edulis. Genetic diversity of 36 accessions of $P$. edulis using 16 morphological traits was assessed and highly significant variation among the accessions for all the analyzed traits except length of tuber was reported (Garedew et al., 2013). In another study, $20 \mathrm{P}$. edulis accessions that were assessed using 29 morphological traits showed $75.7 \%$ variance among the accessions (Mekbib, 2007). This study showed that there are accessions collected from different regions of the country but showed genetic similarity, and some of those collected from the same geographic area showed different genetic background. This indicates geographic diversity does not necessarily represent genetic diversity. Similarly, genetic diversity analysis of 20 accessions using 13 traits revealed significant variation of all traits except flower length and leaf width (Soresa, 2017). Recent extensive genetic diversity study of 174 accessions at three environments based on 12 qualitative and 16 quantitative traits also showed a highly significant 
variation among the populations and non-significant environment-population interaction for most of the quantitative traits (Gadissa et al., 2020). The first six principal axes of principal components analysis accounted for $77 \%$ of the total variation. The populations were grouped into four clusters but there was no strong groupings based on geographical locations from where the genotypes were collected. This indicates the historical or contemporary gene flow, particularly tuber exchange among the different geographical regions. Although there are reports of relatively high genetic diversity, still there is a need for more collections and evaluation over multiple locations and seasons for well-refined genetic diversity estimation. However, as the analyzed traits are affected by the environment, the morphological genetic diversity results should be complemented by molecular genetic diversity studies.

\section{Genetic diversity analyses at molecular level}

Assessment of molecular genetic diversity of $P$. edulis was conducted by using inter simple sequence repeat (ISSR) markers for the first time in 2015 (Shiferaw, 2015). The Shannon information index ranged from 0.25 to 0.39 with overall index of 0.48 . Nei's gene diversity ranged from 0.18 to 0.30 with overall mean diversity of 0.33 , and $74.23 \%$ within population variation. Analysis of Molecular Variance (AMOVA) showed within population diversity range of $41.30 \%$ to $65.22 \%$. Another study using the same marker exhibited overall percent polymorphism of 95\%, 0.62 Shannon information index and 0.40 Nei's gene diversity (Gebrehiwet et al., 2019). More extensive study of genetic diversity assessment was conducted by using expressed sequence tag simple sequence repeats (EST-SSRs) derived from $P$. barbatus (Gadissa et al., 2018). The author identified 128 alleles in 12 populations that consisted of 287 individual plants. The results showed gene diversity index range of 0.31 to 0.39 with overall mean of 0.35 . Among the 12 populations, Wenbera, Awi and Wolaita populations showed the highest genetic diversity, and hence these populations can be considered for in situ conservation and identification of genotypes with traits of interest that can be used in breeding programs. AMOVA showed low population differentiation with only $3 \%$ of the total variation accounting for variation among populations. STRUCTURE and cluster analyses did not group the populations into distinct clusters, which may be attributed to historical and contemporary gene flow and also the reproductive biology of the crop.

\section{Conclusions}

P. edulis is a high potential food security crop containing substantial amounts of nutrients. However, there is no any improved variety of the crop, and currently its cultivation is declining. Shortage of tuber seed is the major problem of this crop. Recently, the farmers are turning to produce other cash crops that generate more income. With advances in plant research, it is important to integrate both conventional and modern technologies to improve this crop. Unless urgent attention is given to such neglected and underutilized crops, these crops are extremely subjected to genetic erosion as the farmers shy away from producing them. Using biotechnological research tools such as plant tissue culture, genetic engineering, genome editing and plant molecular breeding might be a future hope for improvement of this crop, although the international funding opportunities for such orphan crops are highly limited. In vitro propagation and in vitro regeneration protocols from different explants have already been developed as reviewed in this article and these protocols can be used for improvement of $P$. edulis. In addition, information from the genetic diversity results reported so far could be used as a baseline for more research in the area and improve this crop using genomic tools including marker assisted breeding.

\section{Acknowledgements}

The author acknowledges Addis Ababa University for providing the necessary resources during writing of this review. The author is also grateful to graduate students who have been working with him and other researchers who generated interesting information on Plectranthus edulis that served as resources to write this review.

\section{References}

ALVANI K., QI X., TESTER R.F., SNAPE C.E., 2011 - Physicochemical properties of potato starches. - Food Chem., 125(3): 958-965.

ASCHALE N., FEYISSA T., 2019 - In vitro regeneration of Plectranthus edulis (Vatke) from leaf derived callus. - 
Int. J. Res. Agric. Sci., 6(2): 2348-3997.

ASSEFA A., 2015 - Physicochemical characterization of Plectranthus edulis (Ethiopian potato) starch and its evaluation as a disintegrant in paracetamol tablet formulations. - MSc Thesis, Addis Ababa University, Addis Ababa, Ethiopia.

BRHANE Y., 2020 - Evaluation of carboxymethylated Plectranthus edulis starch as a suspending agent in metronidazole benzoate suspension formulations. PLOS ONE, 15(3): e0228547.

BRYAN J.E., 1983 - The importance of planting material in root and tuber crop production, pp. 4. - In: JAMES H.C. (ed.). Global workshop on root and crop propagation. Proceedings of Regional Workshop held in Cali, Colombia, 13-16 September, pp. 236.

DE BOEF W.S., 2008 - Agrobiodiversity, conservation strategies and informal seed supply, pp. 125-132. - In: THIJSSEN M.H., Z. BISHAW, A. BESHIR, and W.S. DE BOEF (eds). Farmers, seeds and varieties: Supporting informal seed supply in Ethiopia. Wageningen International, Wageningen, The Netherlands.

DE KLERK G-J., 2002 - Rooting of microcuttings: Theory and practice. - In vitro Cell. Dev. Biol. - Plant, 38: 415-422.

DEMISSIE A., 1988 - Potentially valuable crop plants in a Vavilovian center of diversity, pp. 89-98. - In: ATTERE F., H. ZEDAN, N.Q. NG, and P. PERRINO (eds.) Ethiopian Crop Genetic Resources of Africa. Proceedings of the International Conf. on Crop Genetic Resources of Africa. Nairobi, Kenya, 26-30 September, IBPGR Int. Board for Plant Genetic Resources, Rome, Italy.

EHNRI, 1997 - Food Composition Table for Use in Ethiopia. EHNRI, Ethiopian Health and Nutrition Research Institute, Addis Ababa, Ethiopia.

FAO, 2010 - The Second Report on the State of the World's Plant Genetic Resources for Food and Agriculture. FAO, United Nations Food and Agriculture Organization, Rome, Italy.

GADISSA F., KASSAHUN T., DAGNE K., GELETA M., 2018 Genetic diversity and population structure analyses of Plectranthus edulis (Vatke) Agnew collections from diverse agroecologies in Ethiopia using newly developed EST-SSRs marker system. - BMC Genetics, 19: 92.

GADISSA F., TESFAYE K., DAGNE K., GELETA M., 2020 Morphological traits based genetic diversity assessment of Ethiopian potato [Plectranthus edulis (Vatke) Agnew] populations from Ethiopia. - Genet. Res. Crop Evol., 67: 809-829.

GAREDEW W., TSEGAYE A., TESFAYE B., MOHAMMED H., 2013 - Diversity analysis in Plectranthus edulis (Vatke) Agnew collection in Ethiopia. - Int. J. Biodivers. Conserv., 5(9): 561-566.

GEBREHIWET M., HAILESELASSIE T., GADISSA F., KASSAHUN T., 2019 - Genetic diversity analysis in Plectranthus edulis (Vatke) Agnew populations collected from diverse geographic regions in Ethiopia using inter-simple sequence repeats (ISSRS) DNA marker system. - J. Biol. Res-Thessaloniki, 26: 7.

HELLEMANS T., ABERA G., DE LEYN I., VAN DER MEEREN P., DEWETTINCK K., EECKHOUT M., DE MEULENAER B., BOCKSTAELE F.V., 2017 - Composition, granular structure, and pasting properties of native starch extracted from Plectranthus edulis (Oromo dinich) tubers. - J. Food Sci., 82(12): 2794-2804.

IBC, 2005 - Ethiopia Third National Report. - Institute of Biodiversity Conservation, Addis Ababa, Ethiopia.

IBC, 2007 - Country report on the State of plant genetic resources for food and agriculture. - Institute of biodiversity conservation, Addis Ababa, Ethiopia.

KARTHA K.K., GAMBORG O.L., 1975 - Elimination of cassava mosaic disease by meristem culture. Phytopathology, 65: 826-828.

LEMA A., 2016 - Comparison and determination of selected essential and non-essential metals in the edible parts of Coccinia abyssinica and Plectranthus edulis tuber crops cultivated in Abay Chomen District of Oromia Region, Ethiopia. - Int. J. Agric. Innov. Res., 5(3): 2319-1473.

LIN J.H., KAO W.T., TSAI Y.C., CHANG Y.H., 2013 - Effect of granular characteristics on pasting properties of starch blends. - Carbohydr. Polym., 98(2): 1553-1560.

LOMMEN W.J.M., STRUIK P.C., 1994 - Field performance of potato minitubers with different fresh weights and conventional seed tubers: Crop establishment and yield formation. - Potato Res., 37: 301-313.

LU Z.H., DONNER E., YADA R.Y., LIU Q., 2012 - The synergistic effects of amylose and phosphorus on rheological, thermal and nutritional properties of potato starch and gel. - Food Chem., 133(4): 1214-1221.

MATHENGE L., 1995 - Nutritional value and utilization of indigenous vegetables in Kenya, pp. 76-77. - In: GUARINO L. (ed.). Traditional African vegetables. Proceedings of the IPGRI international workshop on genetic resources of traditional vegetables in Africa: conservation and use, ICRAF, Nairobi, Kenya. The World Agroforestry Centre, Nairobi, Kenya, 29-31 August.

MEGERSA M., 2010 - Ethnobotanical study of medicinal plants in Wayu Tuka Wereda, east Wollega Zone of Oromia Region, Ethiopia. - M. Sc. Thesis, Addis Ababa University, Addis Ababa, Ethiopia.

MEKBIB Y., 2007 - Phenotypic variation and local customary use of Ethiopian potato (Plectranthus edulis (Vatke) Agnew). - MSc Thesis No. 40, Swedish Biodiversity Center, Swedish University of Agricultural Sciences, Uppsala, Sweden.

MEKBIB Y., WEIBULL J., 2012 - Local customary use and management of Ethiopian potato (Plectranthus edulis (Vatke) Agnew) in Sodo Zuria District, South Ethiopia. Ethnobot. Res. Appl., 10: 381-387.

MURASHIGE T., SKOOG F., 1962 - A revised medium for rapid growth and bioassays with tobacco tissue cultures. - Physiol. Plant., 15: 473-497.

NEGRI V., 2003 - Landraces in central Italy: Where and why they are conserved and perspectives for their on-farm 
conservation. - Genet. Res. Crop Evol., 50: 871-885.

PADULOSI S., HODGKIN T., WILLIAMS J.T., HAQ N., 2002 Underutilized crops: trends, challenges and opportunities in the $21^{\text {st }}$ Century, pp. 323-338. - In: ENGELS J.M.M., R.V. RAMANATHA, A.H.D. BROWN, and M.T. JACKSON (eds). Managing plant genetic diversity. IPGRI, Rome, Italy. pp. 487.

SHIFERAW I., 2015 - Genetic diversity of Oromo potato (Plectranthus edulis (Vatke) Agnew) as revealed by inter simple sequence repeat markers (ISSR). - MSc Thesis, Haramaya University, Haramaya, Ethiopia.

SMOLDERS H., 2006 - Editor of Enhancing Farmers' Role in Crop Development: Framework information for participatory plant breeding in farmers' field schools. - PEDIGREA publication, Center for Genetic Resources, Wageningen, The Netherlands.

SORESA D.N., 2017 - Phenotyping, heritability and genetic advance for oromo potato (Plectranthus edulis) accessions at Horro and Guduru Districts, Western Ethiopia. Int. J. Innov. Res. Dev., 6(5): 91-96.

SPITTERS C.J.T., 1990 - Crop growth models: their usefulness and limitations. - Acta Horticulturae, 267: 349367.

TAGGART P., 2004 - Starch as an ingredient: manufacture and applications, pp. 363-392. - In: ELIASSON A.C. (ed.). Starch in food: structure, function and applications. Woodhead Publishing Limited Cambridge, UK, pp. 624.

TAYE M., 2008 - Studies on agronomy and crop physiology of Plectranthus edulis (Vatke) Agnew. - PhD Thesis,
Wageningen University, Wageningen, The Netherlands.

TAYE M., LOMMEN W.J.M., STRUIKB P.C., 2013 - Seasonal light interception, radiation use efficiency, growth and tuber production of the tuber crop Plectranthus edulis. - Eur. J. Agron., 45: 153-164.

TAYE M.T., LOMMEN W.J.M., STRUIK P.C., 2007 Indigenous multiplication and production practices for the tuber crop Plectranthus edulis in Chencha and Wolaita, southern Ethiopia. - Exp. Agric., 43: 381-400.

TAYE M.T., LOMMEN W.J.M., STRUIK P.C., 2012 - Ontogeny of the tuber crop Plectranthus edulis (Lamiaceae). - Afr. J. Agric. Res., 7(30): 4236-4249.

TSEGAW M., FEYISSA T., 2014 - Micropropagation of Plectranthus edulis (Vatke) Agnew from meristem culture. - Afri. J. Biotechnol., 13(36): 3682-3688.

WATERSCHOOT J., GOMAND S.V., FIERENS E., DELCOUR J.A., 2015 - Production, structure, physicochemical and functional properties of maize, cassava, wheat, potato and rice starches. - Starch, 67(1-2): 14-29.

WIERSEMA S.G., CABELLO R., 1986 - Comparative performance of different-sized seed tubers derived from true potato seed. - Am. Potato J., 63: 241-249.

YIMAM T., 2013 - Effect of solid and liquid media on in vitro shoot proliferation of Plectranthus edulis (Vatke) (Agnew) using TDZ and BAP. - MSc Thesis, Addis Ababa University, Addis Ababa, Ethiopia.

ZIMMERMAN R.H., 1988 - Micropropagation of woody plants: Post tissue culture aspects. - Acta Horticulturae, 227: 489-499. 
